\title{
Relationship between Person Job Fit and Psychological Ownership in the Successor of Family Business
}

\author{
Nynda Rahmayanti and Jimmy Ellya Kurniawan
}

School of Psychology, Universitas Ciputra, Surabaya

\begin{abstract}
Many family businesses fail to regenerate because of a lack of psychological ownership in the successor. Biologically they have the right of heirs to own a family business, but psychologically they don't necessarily feel they own the business. One possible lack of psychological sense of ownership is because the successor feels the jobs he has to do in the family business is not in accordance or relevant with their personal passion. The purpose of this study is investigating the relationship between person job fit and psychological ownership in family business successors. Research data was collected by distributing questionnaires consisting of two scales to 117 students in the family business class at University X. All of these students were successors of family business. The results showed a positive relationship between person job fit and psychological ownership in family business successors. The higher the person job fit, the higher their psychological ownership, and vice versa. Person job fit is positively correlated to the four dimensions of psychological ownership, especially on the self-identity dimension which has the strongest correlation.
\end{abstract}

Corresponding Author: Jimmy Ellya Kurniawan jimmy.ellya@ciputra.ac.id

Received: 30 December 2019 Accepted: 29 January 2020 Published: 6 February 2020

Publishing services provided by Knowledge E

(c) Nynda Rahmayanti and

Jimmy Ellya Kurniawan. This

article is distributed under the terms of the Creative Commons Attribution License, which permits unrestricted use and redistribution provided that the original author and source are credited.

Selection and Peer-review under the responsibility of the 6 th ICOEN 2019 Conference Committee.

Keywords: family business, person job fit, psychological ownership

\section{Introduction}

Family business is a business that is controlled and involves the influence of family members in the process [1]. The survey results conducted by Pricewaterhouse Coopers [2] resulted in data findings that as many as $95 \%$ of companies in Indonesia are family companies. Forbes India explains that $70 \%$ of family businesses fail before being passed on to the second generation, even nearly $90 \%$ do not make it to the third generation [3]. Liputan 6 wrote a news that there are many large companies in Indonesia that start from family businesses [4].

There are expressions that are often identified in the family business namely "first generation build, second generation enjoy, and third generation destroy". This expression arises because many family businesses fail to survive until the next generation. 
Forbes India [3] says that poor succession planning, a lack of trusted advisors, family conflicts, different generations of vision, lack of financial education for children who will continue their business are some of the main reasons why family businesses can failed to the successor. Ward in his book explains that family business faces various challenges including the first lack of financial management skills or skills of employees [5]. Second, the problems of one's own family as an example of the increasing demands of family families make business owners tempted to take advantage of business rather than invest it. Competition between siblings to run a family business, the desire of children to pursue a field they like and not depend on parents can be a thing that can hinder the succession process so that most families do not make succession efforts because they are considered to destroy their families.

Family business has several aspects that are considered to be of a nature detrimental, for example distribution uneven strength, the role of the family that can lead to illogical decision making in the business world due to the element of kinship, the emergence of tolerance in responding to incompetent family members, the emergence of conflict in running a business that can divide families or vice versa [6, 7]. According to Stavrou \& Swiercz the previous generation had the desire to divert their family business to the successor, but in general the successor did not have interest or did not have competencies that were in accordance with the family business [8]. Stavrou [9] in his research with students produced findings that generally the intention of the successor to join or not join a family business is significantly influenced by individual needs, goals, skills and abilities of the individual. According to Ward the desire of children to pursue the fields they like and not depend on parents is one of the conflicts that often occur in family businesses [5].

According to Mahto, Ahluwalia, \& Khanin with the existence of psychological ownership that is owned by the successor can reduce conflicts that occur in the family business, besides that it can also increase the commitment of the successor so they try to work hard to develop the family business [10]. Avey, Avolio, Crossley and Luthans said that Psychological ownership is an individual feeling where he feels that he is part of his workplace. Family businesses need to instill a sense of psychological ownership of the family business to the successor by involving them in running the business [11]. Psychological ownership has 4 dimensions, namely self-efficacy, accountability, selfbelongingness, and self identity [11]. Chirico said that psychological ownership refers to the emotional feelings possessed by family members on family business, a sense of identity, place of residence, strong responsibility and control [12]. 
Stavrou in his research with students produced findings that generally the intention of the successor to join or not join a family business is significantly influenced by the individual's needs, goals, skills and abilities of the individual [9]. There are some things that are desired in the successor of family businesses including integrity, commitment to the family business, decision-making abilities, interpersonal skills and self-confidence $[13,14]$. According to Morris, Williams, \& Nel one of the factors that influence the success of choosing the successor is the extent to which the successor has the ability, skills, knowledge and attitude to run a family business [15]. Compatibility between knowledge, skills and abilities of individuals with job demands is called person job fit. According to Kristof-Brown, Zimmerman, \& Johnson, Person Job Fit is divided into two perspectives, namely the suitability of the knowledge, skills, and abilities of individuals with the work needed and the suitability of the needs, desires and preferences of employees with the work itself [16].

Previous research shows that there is a positive relationship between person job fit and psychological ownership on employees who work in the office [17]. The researcher intends to examine the relationship between person job fit and psychological ownership with different contexts, namely the successor of family business. Employee characteristics differ from the characteristics of members in family businesses, where family business members often exhibit more positive behavior than employees because family business values are usually aligned with family values themselves [18].

This research was conducted because as the successor of family business it is very important to be able to have the ability that is in accordance with the demands of the work, so that it can show good work performance. With good work performance, the family business can continue to grow and develop until it can continue to the successor. Researchers suspect that there is a positive relationship between person job fit and psychological ownership in the successor of family business.

The purpose of this study was to determine the relationship between person job fit and psychological ownership in the successor of family business. The hypothesis in this study is that there is a positive relationship between person job fit and psychological ownership in the successor of family business. Based on the hypothesis it can be interpreted that the higher the person job fit, the higher the psychological ownership of the individual. Likewise vice versa, the lower the person job fit, the lower the psychological ownership of the individual. 
The results of the research can benefit the psychology of family business. This research also provides practical benefits for students as the successor of family businesses, parents, and educational institutions that are able to develop students' business skills.

\section{Methods}

The variables in this study are person job fit as an independent variable and psychological ownership as dependent variables. The high and low suitability of individual knowledge of their work is seen from the total score obtained in the person job fit questionnaire. The higher the score obtained shows the more appropriate the individual's knowledge of his work. Contrarily, the lower the total score of the person job fit, the lower the suitability of the individual's knowledge of the job. While the high and low psychological ownership is seen from the total score obtained from the psychological ownership questionnaire. The higher the total score obtained, the higher the psychological ownership of individuals and vice versa.

This study uses quantitative research methods with correlational design. Methods of collecting data using the online questionnaire method. The questionnaire used contains a scale that measures person job fit belonging to Brkich et al [19]. The scale of psychological ownership belonging to Avey et al [11]. The scale of person job fit consists of 9 item. Aitem consists of statements that measure the suitability of knowledge, the abilities an individual has towards his work in the family business. This measure consists of a scale ranging from 1 (strongly disagree) to 5 (strongly agree). The scale of psychological ownership consists of 20 items. The item represents the four psychological ownership dimensions, namely, 5 aspects of the dimensions of self efficacy, 5 aspects of the accountability dimension, 5 dimensions of the sense of defense, and 5 items in the self identity. Item contains related statements about how individuals feel about their family business. Consists of a scale ranging from 1 (strongly disagree) to 5 (strongly agree).

The subject of this study consisted of 117 students of 2016 and 2017 who joined the guild family business at university X. Students of 2016 and 2017 who joined the family business guild were selected based on the guild's requirement that students must have a family business at least 3 years old so that can enter the guild. Guild family business provides knowledge and support to students who are also the successor of their family business. Students in both these forces obtain guidance on family business for once a week together with lecturers who already berpengalam's in the family business field. 
The technique used in this study is the total population study. This technique uses all members of the population as research subjects.

The results of the person job fit scale reliability test in this study showed Cronbach's Alpha value of 0.808 . While the results of reliability scale psychological ownership the dimension of self efficacy is 0.846 , the accountability dimension is 0.639 , the dimension of sense of belongingness is 0.881 , and the dimension of self identity is 0.766 . The normality test in this study uses Kolmogorov-Smirnov and hypothesis testing using Spearman's Rank Corellation.

\section{Results}

Before conducting a hypothesis test, the researcher first tests the assumptions. In this study, the assumption test carried out was a normality test. The results of the normality test use statistical tests Kolmogorov Smirnov shows that the data is abnormally distributed $\mathrm{KS}=0.037$.

TABLE 1: Descriptive Results Normality Test.

Variable
Psychological ownership

Psychological ownership
Sig. Kolmogorov smirnov

0.037

\section{Conclusion}

Abnormal

Because the data is not normally distributed, the correlation test uses statistical tests Sperman's Rank Correlation. Correlation test results between person job fit and psychological ownership variables indicate that the two variables have a significant positive relationship $(\rho=0.585: p=0,000 ; p<0.05)$.

TABLE 2: Correlation between Person Job Fit and Psychological Ownership.

Variable
Person Job Fit and Psychological
Ownership (Spearman)

*) $p<0.01$
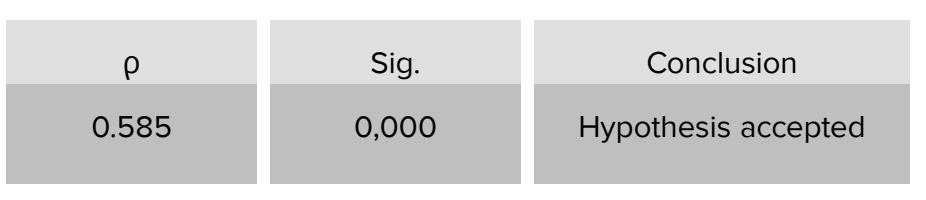

The hypothesis in this study can be accepted that there is a positive relationship between person job fit and psychological ownership to the successor family business. So that the higher the individual person job fit, the higher their psychological level of ownership. Conversely the lower the person job fit individual, psychological level, the lower their ownership. 
TABLE 3: Correlation between Person Job Fit and Psychological Ownership.

\begin{tabular}{l|c|c} 
Variable & $\rho$ & Sig. \\
\hline Self-efficacy & 0.496 & 0.000 \\
\hline Accountability & 0.427 & 0.000 \\
\hline Sense of Belongingness & 0.548 & 0.000 \\
\hline Self Identity & 0.607 & 0.000
\end{tabular}

*) $p<0.01$

\section{Discussion}

The existence of a positive relationship between person job fit and psychological ownership shows that the successor of families who have the ability in accordance with the business field will have psychological ownership in their family business. Likewise with high psychological ownership, the successor of family businesses will show their ability to run a family business well. The results of this study are consistent with the research conducted by Han, Chiang, \& Chiang [17] that person job fit has a positive relationship with psychological ownership, which indicates that the person job fit will help employees show their psychological ownership so as to improve the performance of employees.

The dimension of self-identitiy has the highest correlation value because individuals who feel the work is appropriate and the company is able to meet the individual's needs, there will be positive feelings towards their work [17]. Self identity is formed from various social roles that are being undertaken by individuals, so when individuals have abilities that are appropriate to the place where they work and are able to meet their individual needs, then the individual feels that he represents the identity of the organization [20].

\section{Conclusion}

The conclusion of this study is that there is a positive relationship between person job fit and psychological ownership in the successor of family businesses. The dimension of self-identitiy has the highest correlation with psychological ownership. This research suggests that successors of family businesses are given the opportunity to develop businesses that are in line with their passions to improve their psychological ownership. 


\section{Conflict of Interest}

The authors have no conflict of interest to declare.

\section{References}

[1] Fahed-Sreih, J.; Djoundourian, S. (2006). Determinants of Longevity and Success in Lebanese Family Business: an exploratory study. Family Business Review, 19(3): 225-234.

[2] Pricewaterhouses Coopers. (2014). Survey Bisnis Keluarga di Indonesia (2014).

[3] Forbes India. (2017). Why do Family Business Disintegrate?. Forbes India. Retrived from: http://www.forbesindia.com/blog/business-strategy/why-dofamilybusinesses-disintegrate/ date 12 February 2019

[4] Liputan 6. (2018). 4 Bisnis Keluarga yang Sukses Berumur Panjang. Liputan 6. Retrived from: https://www.liputan6.com/bisnis/read/3522446/4-bisniskeluarga-diindonesia-yang-sukses-berumur-panjang date 22 September 2018

[5] Ward, J. (2016). Keeping the family business healthy: How to plan for continuing growth, profitability, and family leadership. Springer.

[6] The Jakarta Consulting Group. (2014). Budaya Perusahaan Keluarga. The Jakarta Consulting Group. Retrived from: http://www.jakartaconsulting.com/publications/ articles/familybusiness/budaya-perusahaan-keluarga date 22 September 2018

[7] The Jakarta Consulting Group. (2014). Suksesi dalam Perusahaan Keluarga. The Jakarta Consulting Group. Retrived from: http://www.jakartaconsulting. $\mathrm{com} /$ publications/articles/familybusiness/suksesi-dalam-perusahaan-keluarga date 4 September 2018

[8] Stavrou, E. T., \& Swiercz, P. M. (1998). Securing the future of the family enterprise: A model of offspring intentions to join the business. Entrepreneurship Theory and Practice, 23(2), 19-40.

[9] Stavrou, E. T. (1999). Succession in family businesses: Exploring the effects of demographic factors on offspring intentions to join and take over the business. Journal of small business management, 37(3), 43.

[10] Mahto, R. V., Ahluwalia, S., \& Khanin, D. (2014). Psychological ownership of family firm successors: a conceptual approach. Small Business Institute Journal, 10(2), 65-76.

[11] Avey, J. B., Avolio, B. J., Crossley, C. D., \& Luthans, F. (2009). Psychological ownership: Theoretical extensions, measurement and relation to work outcomes. Journal of 
Organizational Behavior: The International Journal of Industrial, Occupational and Organizational Psychology and Behavior, 30(2), 173-191.

[12] Chirico, F. (2008). Knowledge accumulation in family firms: Evidence from four case studies. International Small Business Journal, 26(4), 433-462.

[13] Sharma, P. and Irving, P.G. (2005). Four bases of family business successor commitment: Antecedents and consequences. Entrepreneurship Theory and Practice,1, (pp. 13-33).

[14] Sharma, P. and Rao, S.A. (2000). Successor attributes in Indian and Canadian firms: A comparative study. Family Business Review, 13, (pp. 313-330).

[15] Morris, M. H., Williams, R. W., \& Nel, D. (1996). Factors influencing family business succession. International Journal of Entrepreneurial Behavior \& Research, 2(3), 6881.

[16] Kristof-Brown, A. L., Zimmerman, R. D., \& Johnson, E. C. (2005). Consequences of Individuals'fit at Work: A Meta-Analysis of Person--Job, Person-- Organization, Person--Group, And Person--Supervisor Fit. Personnel psychology, 58(2), 281-342.

[17] Han, T., Chiang, H., \& Chiang, C. (2013). The Investigation of the Relation between Person organization Fit, Person-job Fit, Psychological Ownership, and Contextual Performance: A Longitudinal Approach. In Proceedings of the International Symposium on Marketing, Logistics, and Business (MLB).

[18] Davis, J. H., Allen, M. R., \& Hayes, H. D. (2010). Is blood thicker than water? A study of stewardship perceptions in family business. Entrepreneurship Theory and Practice, 34(6), 1093-1116.

[19] Brkich, M., Jeffs, D., \& Carless, S. A. (2002). A global self-report measure of personjob fit. European Journal of Psychological Assessment, 18(1), 43.

[20] Miscenko, D., \& Day, D. V. (2016). Identity and identification at work. Organizational Psychology Review, 6(3), 215-247. 